\title{
THE COMPOSITION AND STRUCTURE OF FINANCIAL REPORTING - SIMILARITIES AND DIFFERENCES IN THE CASE OF AIR TRANSPORT COMPANIES
}

\author{
Luminița Rus ${ }^{1}$ \\ Mariana Farcaş ${ }^{2}$
}

\begin{abstract}
This report presents three components of annual financial statements - Balance Sheet, Profit and Loss Statement and Statement of Cash Flows - in terms of national and international accounting regulations as a source of information and presentation of the company. Also, through the comparative analysis of annual financial statements of five airlines from different countries, how the format and their presentation influence or condition the relevance of accounting information.
\end{abstract}

Key words: Balance sheet, Income statement, Cash flow statements

JEL Codes: $M 41$

\section{Introduction}

Given the variety of users of accounting information that is multiple and different, both in terms of accounting knowledge and specific information, needs to be noted that financial statements are those that must respond in a manner accessible to all information needs.

The financial statements are intended to present accurate information, true to life and help anyone, regardless of their background: manager, investor, bank, business partner, creditor, employee or state.

Composition of financial statements differs depending on the specific of the country of origin of companies and the accounting conceptual framework, noticeable lately is a trend to harmonize national legislation with international accounting standards.

The objective of the research is to highlight the extent to which the structure, the format and the presentation of information in the Balance sheet, Profit and loss statement and Statement of cash flow influence or condition the relevance of financial accounting information.

To achieve this goal we used the comparative analysis of annual financial statements of five airlines from different countries: Delta Airlines, Inc. (USA), British Airways (Great Britain), Air France - KLM (France), Turkish Airline (Turkey) and Tarom SA (Romania).

\section{The source of information and research methodology}

Users of accounting information are different, resulting in a different interest for information. The confidential information is for internal use while the public information is for to external users. This public information is systematic in financial reporting as documents of synthesis and accounting reporting (Briciu Sorin, 2006).

Over time, changes in regulations affecting accounting and normalizing financial reporting resulted in the presentation of the entity's financial position and performance. Starting from the countries of origin for particular companies to countries where they operate through subsidiaries or

\footnotetext{
${ }^{1}$ University of Oradea, Faculty of Economics, Romania,e-mail: lumimar@gmail.com

${ }^{2}$ University of Oradea, Faculty of Economics, Romania, e-mail: marianafarcasise@yahoo.com
} 
joint ventures, accounting regulations had to take into account some elements of the presentation of the entity's property so that the accounting information provided by them to be useful both country of origin and country of business. It sees such an harmonization of internal legislation with international accounting standards.

The research methodology consisted on the one hand, the literature review - I will mention here the essay of Sorin Briciu, Maria Berheci, Mihai Ristea, Camelia Iuliana Lungu, International Accounting Standard IAS 1 and others authors.

On the other hand, it has been analyzed annual financial reports of some popular airlines: Delta Airlines, British Airways, Air France-KLM and Turkish Airline Tarom SA Romania, highlighting the essential elements presented to them.

\section{Financial statements - regulation, structure, example}

In the process of the implementation of the Fourth European Directive, Minister of Finance Order 3055/2009 defines the characteristics of financial accounting information stating vis-à-vis the relevance that "information is relevant when it influences the economic decisions of users, helping they assess past, present, or future, to confirm or correct their previous evaluations. " If in certain situations, the nature of information is sufficient to determine its relevance, in other situations, the significance comes to complete the nature of the information to make it relevant.

Information is considered significant when its omission or erroneous presentation influence the decisions of users. In this respect, in some cases, laws obstruct and coercion, materiality, playback of information in financial statements. (Cernusca Liviu, 2004)

The relevance of information, as a qualitative feature is supported by all reference of (Lungu Camelia Iuliana, 2007) even if the methods of presentation are different. It should be considered in developing the complete set of financial statements.

IAS 1 establishes a minimum set of information that can be extended by additional sections to clarify or detail some of the elements of financial statements, if a legal regulation request it or if they are necessary for a proper financial structure. Also, the rule does not prescribe the order or format in which items must be presented allowing entities a choice. (Feleagă Niculae, 2000 and Ionescu Cicilia, 2003).

According to British referential, in the process of taking the decision to include or not a certain information in the financial statement, there are analyzed the value and the nature of the item, the signification given by this to the financial statement being considered an independent feature and most important. (Lungu Camelia Iuliana, 2007).

In terms of Profit and Loss Statement, IAS 1 gives the possibility of presentation of income and expenditure by function or by nature. If classified by function, the entities must provide the supplementary information about the nature of expenses. (Feleagă Niculae, 2000)

Fourth European Directive presents a great flexibility in terms of Profit and Loss Statement giving a choice of four schemes: two as a list and two that groups the expenditure according to their origin, or their destination. (Ionescu Cicilia, 2003).

The cash flow statement groups the variation of cash and equivalents of cash by operating activity, investing and financing, the objective of cash flow statement being to inquire information about the history of the movement of cash and cash equivalents of an enterprise. (IAS 7)

U.S.A.

The financial reports, established by the FASB (Financial Accounting Standards Board), provides useful information on the evaluation of economic resources, the changes of these resources, as well as important elements in making investments or financing decisions.

U.S. companies prepare financial reports which include: Balance sheet, Income statement, Statement of Cash Flows, Statement of Stockholders Equity and Notes to Financial statements. 
There is no obligation of Balance sheet in a standardized form, it can be submitted to the list (Portrait) or horizontal format (Landscape format) comparison for two years, the format being the most common form of list, such as that described in Table. 1.

U.S. agencies for normalization of accounting have not established any format for profit or loss, SFAC 6: Elements of Financial Statement "following only the calculation of global net to include all income, expenses, gains or losses arising during the period corresponding to the Table. 2

Statement of cash flows is governed by SFAS 95 "Statements of Cash Flows" Cash flows grouping following categories: operating activities, investing activities and financing activities, exemplified in Table 3.

Example: Delta Airlines, Inc.

Tabel no.1.

Consolidated Balance Sheets

\begin{tabular}{|c|c|c|}
\hline & \multicolumn{2}{|c|}{ (in millions \$) } \\
\hline & \multicolumn{2}{|c|}{ December 31} \\
\hline & 2010 & 2009 \\
\hline \multicolumn{3}{|c|}{ Assets } \\
\hline Current Assets & 7,307 & 7,991 \\
\hline Property and Equipment, Net & 20,307 & 20,433 \\
\hline Other Assets & 15,574 & 15,365 \\
\hline Total assets & 43,188 & $\mathbf{4 3 , 7 8 9}$ \\
\hline \multicolumn{3}{|c|}{ Liabilities and Stockholders' Equity } \\
\hline Current Liabilities & 11,385 & 9,797 \\
\hline Noncurrent Liabilities & 30,906 & 33,747 \\
\hline \multicolumn{3}{|c|}{ Commitments and Contingencies } \\
\hline Stockholders' Equity & 897 & 245 \\
\hline Total Liabilities and Stockholders' Equity & 43,188 & 43,789 \\
\hline
\end{tabular}

Source: www.delta.com

Comments: Current Assets includes: Cash and cash equivalents, Short-term investments, restricted cash, cash equivalents and short-term investments, Accounts receivable, net of an allowance for uncollectible accounts of $\$ 40$ and $\$ 47$ at December 31, 2010 and 2009, respectively, Expendable parts and supplies inventories, net of an allowance for obsolescence of \$104 and \$75 at December 31, 2010 and 2009, respectively, Deferred income taxes, net, Prepaid expenses and other.

Property and equipment are presented as net of accumulated depreciation and amortization of \$4,164 and \$2,924 at December 31, 2010 and 2009, respectively.

Other Assets includes: Goodwill, Identifiable intangibles, net of accumulated amortization of \$530 and \$451 at December 31, 2010 and 2009, respectively, Other noncurrent assets.

Current Liabilities presents: Current maturities of long-term debt and capital leases, Air traffic liability, Accounts payable, Frequent flyer deferred revenue, Accrued salaries and related benefits, Taxes payable, Other accrued liabilities.

Noncurrent Liabilities includes: Long-term debt and capital leases, Pension, postretirement and related benefits, Frequent flyer deferred revenue, Deferred income taxes, net, Other noncurrent liabilities.

Stockholders' Equity includes: Additional paid-in capital, Accumulated deficit, Accumulated other comprehensive loss, Treasury stock, at cost, 12,993,100 and 10,918,274 shares at December 31, 2010 and 2009, respectively. (www.delta.com) 
Tabel no.2.

Consolidated Statements of Operations

\begin{tabular}{|c|c|c|}
\hline & \multicolumn{2}{|c|}{$\begin{array}{r}\text { (in millions } \$, \text { except } \\
\text { per share data) }\end{array}$} \\
\hline & \multicolumn{2}{|c|}{$\begin{array}{c}\text { Year Ended } \\
\text { December } 31\end{array}$} \\
\hline & 2010 & 2009 \\
\hline Operating Revenue: Passenger, Cargo, Other & 31,755 & 28,063 \\
\hline Operating Expense* & 29,538 & 28,387 \\
\hline Operating Income (Loss) & 2,217 & $(324)$ \\
\hline $\begin{array}{l}\text { Other (Expense) Income: Interest expense, Amortization of debt discount, net, } \\
\text { Interest income, Loss on extinguishment of debt, Miscellaneous, net }\end{array}$ & $(1,609)$ & $(1,257)$ \\
\hline Income (Loss) Before Income Taxes & 608 & $(1,581)$ \\
\hline Income Tax (Provision) Benefit & (15) & 344 \\
\hline Net Income (Loss) & 593 & $(1,237)$ \\
\hline Basic Earnings (Loss) per Share & $\$ 0.71$ & $\$(1.50)$ \\
\hline Diluted Earnings (Loss) per Share & $\$ 0.70$ & $\$(1.50)$ \\
\hline
\end{tabular}

Source: www.delta.com

*Operating Expense include: Aircraft fuel and related taxes, Salaries and related costs, Contract carrier arrangements, Aircraft maintenance materials and outside repairs, Contracted services, Depreciation and amortization, Passenger commissions and other selling expenses, Landing fees and other rents, Passenger service, Aircraft rent, Profit sharing, Impairment of goodwill and other intangible assets, Restructuring and merger-related items, Other

Tabel no.3.

Consolidated Statements of Cash Flows

\begin{tabular}{|c|c|c|}
\hline & \multicolumn{2}{|c|}{ (in millions \$) } \\
\hline & \multicolumn{2}{|c|}{$\begin{array}{l}\text { Year Ended } \\
\text { December } 31\end{array}$} \\
\hline & 2010 & 2009 \\
\hline \multicolumn{3}{|l|}{ Cash Flows From Operating Activities: } \\
\hline Net income (loss) & 593 & $(1,237)$ \\
\hline $\begin{array}{l}\text { Adjustments to reconcile net income (loss) to net cash provided by (used in) operating } \\
\text { activities* }\end{array}$ & 1,961 & 1,927 \\
\hline Changes in certain current assets and liabilities $* *$ & 173 & 856 \\
\hline Other, net & 105 & $(167)$ \\
\hline Net cash provided by (used in) operating activities & 2,832 & 1,379 \\
\hline \multicolumn{3}{|l|}{ Cash Flows From Investing Activities: } \\
\hline $\begin{array}{l}\text { Property and equipment additions, (Increase) decrease in restricted cash and cash } \\
\text { equivalents, (Purchase) redemption of investments, }\end{array}$ & $(2,074)$ & $(1,119)$ \\
\hline Proceeds from sales of flight equipment & 36 & 100 \\
\hline Other, net & 12 & 11 \\
\hline Net cash (used in) provided by investing activities & $(2,026)$ & $(1,008)$ \\
\hline \multicolumn{3}{|l|}{ Cash Flows From Financing Activities: } \\
\hline $\begin{array}{l}\text { Payments on long-term debt and capital lease obligations and Proceeds from long- } \\
\text { term obligations }\end{array}$ & $(2,592)$ & 75 \\
\hline Other, net & 71 & $(94)$ \\
\hline Net cash (used in) provided by financing activities & $(2,521)$ & (19) \\
\hline Net (Decrease) Increase in Cash and Cash Equivalents & $(1,715)$ & 352 \\
\hline Cash and cash equivalents at beginning of period & 4,607 & 4,255 \\
\hline Cash and cash equivalents at end of period & 2,892 & 4,607 \\
\hline
\end{tabular}

Source: www.delta.com

*This line include: Depreciation and amortization, Amortization of debt discount, net, Loss on extinguishment of debt, Fuel hedge derivative instruments, Deferred income taxes, Pension, postretirement and postemployment expense (less than) in excess of payments, Equity-based 
compensation expense, Impairment of goodwill and other intangible assets, Restructuring and merger-related items.

**Changes in certain current assets and liabilities includes: (Increase) decrease in receivables, Decrease (increase) in hedge margin receivables, Decrease in restricted cash and cash equivalents, Increase in prepaid expenses and other current assets, Increase (decrease) in air traffic liability, Decrease in frequent flyer deferred revenue, Increase (decrease) in accounts payable and accrued liabilities

\section{Great Britain}

National regulations on how to prepare annual financial statements are elaborated by the Accounting Standards Board (ASB - Accounting Standards Board) and are known as the FRS (Financial Reporting Standards).

Financial statements prepared under these regulations include: Balance Sheet, Profit and Loss Account, Statement of Total Recognized Gains and Losses, Reconciliation of Movements in Shareholders' Funds, Statement of Cash Flow and Notes.

"The financial statement can be introduced either as a list of assets, followed by equity and debt, or a list of highlighted net assets, preferred by most British businesses. The criterion of grouping items in the balance is based on current / noncurrent. "(Ristea Mihai et al, 2006), such as shown in Table 4.

Profit and loss account prepared by UK companies is generally presented as a list, not loaded with information, details being made in the notes. He should be drafted to allow financial markets to establish forecasts on future performance of the company.

"FRS 22" Earning per Share "requires disclosure in the profit and loss of earnings per share for basic and diluted net income, but also the profit or loss from continuing operations. Diluted earnings per share and the related profit or loss from discontinued operations can be reported in the income statement or in notes to financial statements. (Ristea Mihai et al, 2006), exemplified in the Table. 5

Statement of cash flows has a special structure, grouping the following items: Operating activities, income from investments and financing services, income taxes, investment activities, receipts and payments generated by the sale or acquisition of assets, dividends on capital of company, cash management, and financing activities. A model is presented in Table no. 6.

\section{Example: British Airways}

Comment: Fiscal year starting April 1 and ending March31.

Consolidated Balance Sheets

Tabel no.4.

\begin{tabular}{|c|c|c|c|}
\hline & & \multicolumn{2}{|c|}{ (in millions $\mathfrak{f}$ ) } \\
\hline & & Mar & 31 \\
\hline & Note & 2010 & 2009 \\
\hline Property, plant and equipment: Fleet, Property, Equipment & 14 & 6,904 & 7,233 \\
\hline Intangibles: Goodwill, Landind rights, Software & 17 & 269 & 267 \\
\hline $\begin{array}{l}\text { Investments in subsidiaries, Investments in associates, Available-for-sale } \\
\text { financial assets, Employee benefit assets, Derivative financial } \\
\text { instruments, Prepayments and accrued income }\end{array}$ & $\begin{array}{r}19,20, \\
35,31\end{array}$ & 800 & 642 \\
\hline Total non-current assets & & 7,973 & 8,142 \\
\hline Non-current assets held for sale & 16 & 30 & - \\
\hline Inventories, Trade receivables, Other current assets & $\begin{array}{r}21,22, \\
23\end{array}$ & 886 & 925 \\
\hline Derivative financial instruments & 31 & 74 & 40 \\
\hline Other current interest-bearing deposits and Cash and cash equivalents & 24 & 1,714 & 1,381 \\
\hline Total current assets and receivables & & 2,674 & 2,346 \\
\hline
\end{tabular}




\begin{tabular}{|c|c|c|c|}
\hline Total assets: & & $\mathbf{1 0 , 6 7 7}$ & 10,488 \\
\hline $\begin{array}{l}\text { Shareholders' equity: Issued share capital, Share premium, Investment } \\
\text { in own shares, Other reserves }\end{array}$ & 32,34 & 1,913 & 1,646 \\
\hline Non-controlling interests & 34 & 200 & 200 \\
\hline Total equity & & 2,113 & 1,846 \\
\hline $\begin{array}{l}\text { Non-current liabilities: Interest-bearing long-term borrowings, } \\
\text { Employee benefit obligations, Provisions for deferred tax, Other } \\
\text { provisions. Derivative financial instruments, Other long-term liabilities }\end{array}$ & $\begin{array}{r}27,35 \\
11,29 \\
31,26\end{array}$ & 4,824 & 4,500 \\
\hline $\begin{array}{l}\text { Current liabilities: Current portion of long-term borrowings, Trade and } \\
\text { other payables, Derivative financial instruments, Current tax payable, } \\
\text { Short-term provisions }\end{array}$ & $\begin{array}{r}27,25 \\
31\end{array}$ & 3,740 & 4,142 \\
\hline Total equity and liabilities & & 10,677 & $\mathbf{1 0 , 4 8 8}$ \\
\hline
\end{tabular}

Source: www.britishairways.com

Tabel no.5.

Consolidated Income Statements

\begin{tabular}{|c|c|c|}
\hline & \multicolumn{2}{|c|}{ (in millions $\mathfrak{f}$ ) } \\
\hline & \multicolumn{2}{|c|}{ March 31} \\
\hline & 2010 & 2009 \\
\hline Traffic Revenue: Passenger, Cargo & 7,530 & 8,509 \\
\hline Other revenue & 464 & 483 \\
\hline Revenue & 7,994 & 8,992 \\
\hline Total expenditure on operations* & 8,225 & 9,212 \\
\hline Operating loss & $(231)$ & $(220)$ \\
\hline Financial elements** & $(300)$ & $(181)$ \\
\hline Loss before tax & $(531)$ & $(401)$ \\
\hline Tax & 106 & 43 \\
\hline Loss after tax & $(425)$ & (358) \\
\hline
\end{tabular}

Source: www.britishairways.com

*Total expenditure on operation includes: Employee costs, Restructuring, Depreciation, amortization and impairment, Aircraft operating lease costs, Fuel and oil costs, Engineering and other aircraft costs, Landing fees and en-route charges, Handling charges, catering and other operating costs, Selling costs, Currency differences, Accommodation, ground equipment and IT costs. A part of this expenses are presented in The Notes to Financial Statement 4 and 7.

**Financial elements include: Fuel derivative gains/(losses), Finance costs, Finance income, Net financing expense relating to pensions, Retranslation charges on currency borrowings, (Loss)/profit on sale of property, plant and equipment and investments, Share of post-tax (losses)/profits in associates accounted for using the equity method, Net charge relating to available-for-sale financial assets

Tabel no.6.

Consolidated Statements of Cash Flows

\begin{tabular}{|l|r|r|}
\hline & (in millions \$) \\
\hline & \multicolumn{2}{c|}{$\begin{array}{c}\text { Year Ended } \\
\text { March 31 }\end{array}$} \\
\hline Cash Flows From Operating Activities: & $\mathbf{2 0 1 0}$ & $\mathbf{2 0 0 9}$ \\
\hline Operating loss & $(231)$ & $(220)$ \\
\hline Depreciation, amortization and impairment & 732 & 694 \\
\hline Cash generated from operations* & 461 & 307 \\
\hline Interest paid Net cash generated from operating activities & $(136)$ & $(177)$ \\
\hline Taxation & 6 & 3 \\
\hline & 331 & 133 \\
\hline Cash Flows From Investing Activities: & & \\
\hline Purchase of intangible assets and property, plant and equipment & $(505)$ & $(571)$ \\
\hline
\end{tabular}




\begin{tabular}{|l|r|r|}
\hline Proceeds from sales of other investments, property, plant and equipment & 102 & 12 \\
\hline Other, net** Net cash used in investing activities & 66 & 302 \\
\hline \multicolumn{1}{|c|}{ Net cash flow from financing activities } & $(337)$ & $(257)$ \\
\hline Cash Flows From Financing Activities: & 368 & $(91)$ \\
\hline $\begin{array}{l}\text { Proceeds from long-term borrowings and equity portion of convertible bond, Repayments } \\
\text { of borrowings, Payment of finance lease liabilities }\end{array}$ & $(18)$ & $(74)$ \\
\hline Other, net & 350 & $(165)$ \\
\hline \multicolumn{1}{|c|}{ Net increase/(decrease) in cash and cash equivalents } & 344 & $(289)$ \\
\hline Net foreign exchange differences & 40 & 8 \\
\hline Cash and cash equivalents at 1 April & 402 & 683 \\
\hline Cash and cash equivalents at 31 March & 786 & 402 \\
\hline
\end{tabular}

Source: www.britishairways.com

*Operating cash flow before working capital changes, Movement in inventories, trade and other receivables, Movement in trade and other payables and provisions, Payments in respect of restructuring, Payments in settlement of competition investigation, Other non-cash movement.

**Other, net, include: Insurance recoveries for write-off of Boeing 777 aircraft, Purchase of subsidiary (net of cash acquired), Proceeds received from loan notes, Interest received, Dividends received, Decrease/(increase) in other current interest-bearing deposits

***Cash and cash equivalents at 31 March are presented in The Note 4 to Financial statement.

\section{France}

Financial Reports include financial statements and statement of cash flows, whose publication is not mandatory.

Individual or consolidated accounts comprise the balance sheet, statement of revenue and expenditure, which form an inseparable. Exemplified in Tables 7 and 8 . Statement of cash flow, production of which is recommended by the NCC, in particular for some firms and imposed by law on preventing problems, as part of the annual accounts. The practice, however, shows that two thirds of public listed companies or public groups present the cash flow statement in their annual report, such as that shown in Table. 9

Individual accounts or statements are prepared in accordance with the Commercial Code and the General Accounting Plan.

Example: Air France - KLM

Comment: Fiscal year starting April 1 and ending March31.

Tabel no.7.

\section{Consolidated Balance Sheets}

\begin{tabular}{|c|c|c|}
\hline & \multicolumn{2}{|c|}{ (in millions $€$ ) } \\
\hline & \multicolumn{2}{|c|}{ March 31} \\
\hline & 2010 & 2009 \\
\hline Assets & & \\
\hline Non-current Assets ${ }^{1}$ & 19,755 & 20,720 \\
\hline Current Assets $^{2}$ & 8,020 & 8,053 \\
\hline Total assets & 27,775 & 28,773 \\
\hline Liabilities and Equity & & \\
\hline Equity attributable to equity holders of Air France-KLM & 5,363 & 5,622 \\
\hline Minority interests & 55 & 54 \\
\hline Total equity & 5,418 & 5,676 \\
\hline Total non-current liabilities $^{3}$ & 11,890 & 11,707 \\
\hline Total current liabilities $^{4}$ & 10,467 & 11,390 \\
\hline Total liabilities and equity & 27,775 & 28,773 \\
\hline
\end{tabular}

Source: www.airfranceklm-finance.com 
${ }^{1}$ Non-current assets include: Goodwill, Intangible assets, Flight equipment, Other property, plant and equipment, Investments in equity associates, Pension assets, Deferred tax assets, Other non-current assets

${ }^{2}$ Current assets include: Assets held for sale, Other short-term financial assets, Inventories, Trade accounts receivable, Income tax receivables, Other current assets, Cash and cash equivalents.

${ }^{3}$ Non-current liabilities include: Provisions and retirement benefits, Long-term debt, Deferred tax, Other non-current liabilities

${ }^{4}$ Current liabilities include: Liabilities relating to assets held for sale, Provisions, Current portion of long-term debt, Trade accounts payable, Deferred revenue on ticket sales, Frequent flyer programs, Current tax liabilities, Other current liabilities, Bank overdrafts

Tabel no.8.

Consolidated Income Statements

\begin{tabular}{|c|c|c|}
\hline & \multicolumn{2}{|c|}{ (in millions $€$ ) } \\
\hline & & \\
\hline & 2010 & 2009 \\
\hline Sales & 20,999 & 23,975 \\
\hline Operating expense $^{*}$ & 22,284 & 24,104 \\
\hline Income/(loss) from current operations & $(1,285)$ & $(129)$ \\
\hline $\begin{array}{l}\text { Sales of aircraft equipment, Negative goodwill, Other non-current income and } \\
\text { expenses }\end{array}$ & (347) & (64) \\
\hline Income/(loss) from operating activities & $(1,632)$ & $(193)$ \\
\hline Cost of financial debt, Income from cash and cash equivalents & $(304)$ & $(100)$ \\
\hline Net cost of financial debt & $(193)$ & (911) \\
\hline Other financial income and expenses & $(2,129)$ & $(1,204)$ \\
\hline Income taxes & 586 & 439 \\
\hline Net income/(loss) of consolidated companies & $(1,543)$ & $(765)$ \\
\hline Share of profits/(losses) of associates & (17) & $(42)$ \\
\hline $\begin{array}{l}\text { Net income/(loss) from continuing operations } \\
\text { - Group } \\
\text { - Minority interests }\end{array}$ & $\begin{array}{r}(1.560) \\
(1,559) \\
(1)\end{array}$ & $\begin{array}{r}(807) \\
(814) \\
7\end{array}$ \\
\hline
\end{tabular}

Source: www.airfranceklm-finance.com

*Operating expense include: External expenses, Salaries and related costs, Taxes other than income taxes, Amortization and depreciation, Provisions, Other income and expenses

Consolidated Statements of Cash Flows

Tabel no.9.

\begin{tabular}{|c|c|c|}
\hline & \multicolumn{2}{|c|}{ (in million $€$ ) } \\
\hline & \multicolumn{2}{|c|}{$\begin{array}{l}\text { Year Ended } \\
\text { March 31 }\end{array}$} \\
\hline & 2010 & 2009 \\
\hline Net income, Group & $(1,559)$ & $(814)$ \\
\hline Minority interests & $(1)$ & 7 \\
\hline Adjustments to obtain cash flow generated from operating activities ${ }^{*}$ & 1,317 & 1,309 \\
\hline $\begin{array}{l}\text { (Increase)/decrease in inventories, trade receivables and trade payables or change in } \\
\text { other receivables and payables }\end{array}$ & $(555)$ & 296 \\
\hline $\begin{array}{l}\text { Net cash flow from operating activities } \\
\end{array}$ & (798) & 798 \\
\hline Purchase of intangible assets and property, plant and equipment and intangible assets & $(2,115)$ & $(2,391)$ \\
\hline $\begin{array}{l}\text { Proceeds from sales of other investments, property, plant and equipment and intangible } \\
\text { assets }\end{array}$ & 1,056 & 157 \\
\hline Other, net" & 92 & $(240)$ \\
\hline Net cash used in in investing activities & (967) & (2.474) \\
\hline $\begin{array}{l}\text { Increase in capital, Issuance of long-term debt, Repayments on long-term debt, } \\
\text { Payment of debt resulting from finance lease liabilities, New loans, Repayment on } \\
\text { loans }\end{array}$ & 1,934 & 1,116 \\
\hline
\end{tabular}




\begin{tabular}{|l|r|r|}
\hline Dividends paid, Decrease in equity & $(3)$ & $(187)$ \\
\hline \multicolumn{1}{|c|}{ Net cash flow from financing activities } & $\mathbf{1 , 9 3 1}$ & $\mathbf{9 2 9}$ \\
\hline Effect of exchange rate on cash and cash equivalents and bank overdrafts & 3 & 4 \\
\hline Change in cash and cash equivalents and bank overdrafts & $\mathbf{1 6 9}$ & $\mathbf{( 7 4 3 )}$ \\
\hline Cash and cash equivalents and bank overdrafts at beginning of period & 3,466 & 4,209 \\
\hline Cash and cash equivalents and bank overdrafts at end of period & 3,635 & 3,466 \\
\hline
\end{tabular}

The source: www.airfranceklm-finance.com

*Amortization, depreciation and operating provisions, Financial provisions, Gain on disposals of tangible and intangible assets, Loss/(gain) on disposals of subsidiaries and associates, Reversal of provision for cargo investigation, Derivatives - non-monetary result, Unrealized foreign exchange gains and losses, Negative goodwill, Share of (profits)/losses of associates, Deferred taxes, Other non-monetary items.

** Other means: Dividends received, Decrease/(increase) in investments, net between three months and one year.

\section{Turkey}

The financial statements of the public companies led to the formation and adjustments of financial statements for the private area so that the normalized statement was introduced, including the regulation of the valuation of the financial statements.

In general, the information contained in financial statements must meet the needs of decision makers in the best manner, the information must be quickly and easily to understand, flexible, reliable, timely and should be edited to make them comparable.

The objectives of financial statements are: Usefulness of information for making decisions by investors, creditors and other stakeholders, evaluation of future cash flows, provision of information on its active, and the result of resource exploitation. Financial reports include: Balance Sheet, Profit and loss, The accounting principles and policies used in their preparation.

\section{Example: Turkish Airline}

Tabel no.10.

Consolidated Balance Sheets

\begin{tabular}{|l|c|c|}
\hline \multicolumn{3}{|c|}{ (in Turkish Lira) } \\
\hline \multicolumn{1}{|c|}{} & \multicolumn{2}{c|}{ December 31 } \\
\hline \multicolumn{1}{|c|}{ Assets } & $\mathbf{2 0 0 9}$ & $\mathbf{2 0 0 8}$ \\
\hline & $2,799,855,184$ & $2,620,279,393$ \\
\hline Current Assets & $5,772,234,243$ & $5,290,955,322$ \\
\hline Non-current assets & $\mathbf{8 , 5 7 2 , 0 8 9 , 4 2 7}$ & $\mathbf{7 , 9 1 1 , 2 3 4 , 7 1 5}$ \\
\hline Total assets & & \\
\hline Lurrent Liabilities & $1,949,243,312$ & $1,653,906,994$ \\
\hline Noncurrent Liabilities & $3,177,965,889$ & $3,270,740,625$ \\
\hline \multicolumn{1}{|c|}{ Stockholders' Equity } & & \\
\hline Equity Attributable to Shareholders of Parent & $3,444,880,226$ & $2,986,587,096$ \\
\hline Total Liabilities and Stockholders' Equity & $\mathbf{8 , 5 7 2 , 0 8 9 , 4 2 7}$ & $\mathbf{7 , 9 1 1 , 2 3 4 , 7 1 5}$ \\
\hline
\end{tabular}

The source: www.turkishairlines.com

Current asset includes: Cash and cash equivalents, Financial assets, Trade receivables, Other receivables, Inventories and Other current assets and are presented detailed in The Notes to Financial Statements 8, 9, 10, 11, 22, 24, 26 and 35 .

Non-current asses include: Other receivables, Financial assets, Investments accounted for using the Equity Method, Investment property, Tangible assets, Intangible assets, Deferred tax assets and Other non-current assets and are presented detailed in The Notes to Financial statements , $11,24,26$ and 35 .

Current liabilities include: Financial debt, Other financial liabilities, Trade payables, Other payables, Current tax liabilities, Provisions, Employee benefit obligations, Passenger flight 
liabilities, Other current liabilities and are shown detailed in The Notes 8, 9, 10, 11, 22, 24, 26 and 35 to Financial Statement.

Non-current liabilities include: Financial debt, Other payables, Provision for retirement pay liability, Deferred tax liability, Other non-current liabilities and are shown detailed in The Notes 8 , 11, 24, 26 and 35 to Financial Statement.

Equity Attributable to Shareholders of Parent contain: Share capital, Inflation difference on shareholders' equity, Share premium, Restricted profit reserves, Differences from currency translation, Cash flow hedge fund (-), Retained Earnings, Net Profit/(Loss) for the Period and are shown detailed in The Note 27 to Financial Statement.

Consolidated Statement of Comprehensive Income for The Year Ended

Tabel no.11.

\begin{tabular}{|c|c|c|}
\hline & \multicolumn{2}{|c|}{ (in Turkish Lira) } \\
\hline & \multicolumn{2}{|c|}{ December 31} \\
\hline & 2009 & 2008 \\
\hline Sales revenue & $7,035,882,903$ & $6,123,174,209$ \\
\hline Cost of sales (-) & $(5,135,949,144)$ & $(4,542,670,584)$ \\
\hline Gross profit /(loss) & $1,899,933,759$ & $1,580,503,625$ \\
\hline Marketing. sales and distribution expenses (-) & $(806,503,413)$ & $(635,876,008)$ \\
\hline Administrative expenses (-) & $(261,536,526)$ & $(203,813,181)$ \\
\hline Other operating income & $91,136,104$ & $56,690,528$ \\
\hline Other operating expenses (-) & $(199,139,482)$ & $(210,120,463)$ \\
\hline Operating profit / (loss) & $723,890,442$ & $587,384,501$ \\
\hline $\begin{array}{l}\text { Share of investments' profit/ (loss) accounted for } \\
\text { using the equity method }\end{array}$ & $12,813,703$ & $3,572,374$ \\
\hline Financial income & $172,982,144$ & $1,427,882,203$ \\
\hline Financial expenses (-) & $(172,708,672)$ & $(713,373,140)$ \\
\hline Profit / (loss) before tax & $736,977,617$ & $1,305,465,938$ \\
\hline Tax (expense) / income & $(177,901,337)$ & $(171,239,727)$ \\
\hline Profit / (loss) for the year & $559,076,280$ & $1,134,226,211$ \\
\hline Other comprehensive income / (expense) (after tax) & $(1,569,396)$ & $4,459,406$ \\
\hline Total comprehensive income / (expense) for the year & $557,506,884$ & $1,138,685,617$ \\
\hline Earnings / (loss) per share (Kr) & 0.64 & 1.30 \\
\hline
\end{tabular}

Source: www.turkishairlines.com

The components of Consolidated statement of comprehensive income are prezented in The Notes to Financial Statement 16, 28, 29, 30,31, 32 and 35 .

Tabel no.12.

\section{Consolidated Statements of Cash Flows}

\begin{tabular}{|c|c|c|}
\hline & \multicolumn{2}{|c|}{ (in Turkish Lira) } \\
\hline & \multicolumn{2}{|c|}{ Year Ended December 31} \\
\hline & 2009 & 2008 \\
\hline Net profit before taxes & $736,977,617$ & $1,305,465,938$ \\
\hline $\begin{array}{l}\text { Adjustments to obtain net cash flow generated from } \\
\text { operating activities }\end{array}$ & $427,750,717$ & $63,011,179$ \\
\hline Operating profit before working capital changes & $1,209,728,334$ & $1,368,477,117$ \\
\hline Other increase / (decrease) & $(33,459,740)$ & $(138,819,174)$ \\
\hline Net cash flow from operating activities & $1,176,268,594$ & $1,229,657,943$ \\
\hline Purchase of tangible and intangible fixed assets & $129,348,500$ & $26,482,893$ \\
\hline Proceeds from sales of tangibles and intangible fixed assets ${ }^{* *}$ & $(228,635,897)$ & $(230,333,395)$ \\
\hline Prepayments for the purchase of aircrafts & $(1,331,217,539)$ & $249,984,372$ \\
\hline Other, net ${ }^{* * *}$ & $1,384,921,002$ & $(1,020,457,786)$ \\
\hline $\begin{array}{l}\text { Cash outflow for the purchase of investments accounted at equity } \\
\text { method }\end{array}$ & $(39,418,996)$ & $(4,280,515)$ \\
\hline Net cash used in investing activities & $(85,002,930)$ & $(978,604,431)$ \\
\hline Repayment of principal in finance lease liabilities & $(397,692,584)$ & $(261,788,079)$ \\
\hline
\end{tabular}




\begin{tabular}{|l|r|r|}
\hline Decrease in financial borrowings & $(6,806,885)$ & $(3,917,374)$ \\
\hline Increase in other financial liabilities & $3,650,707$ & $39,361,447$ \\
\hline Dividends paid & $\mathbf{( 9 9 , 2 1 3 , 7 5 4 )}$ & - \\
\hline \multicolumn{1}{|c|}{ Net cash flow from financing activities } & $\mathbf{( 5 0 0 , 0 5 9 , 5 1 6 )}$ & $\mathbf{( 2 2 6 , 3 4 4 , 0 0 6 )}$ \\
\hline Net increase / (decrease) in cash and cash equivalents & $\mathbf{5 9 1 , 2 0 6 , 1 4 8}$ & $\mathbf{2 4 , 7 0 9 , 5 0 6}$ \\
\hline Cash and cash equivalents at beginning of the year & $504,905,721$ & $480,196,215$ \\
\hline Cash and cash equivalents at end of the year & $1,096,111,869$ & $504,905,721$ \\
\hline
\end{tabular}

Source: www.turkishairlines.com

*This include Depreciation and amortization, Provision for retirement pay liability, Interest income, Profit/(loss) on sales of fixed assets, Increase/(decrease) in provision for impairment, Loss/(profit) on equity investments accounted for using the equity method, Interest expense, Movement in manufacturers' credit, Unrealized foreign exchange loss/(gain) on finance leases, Increase/(decrease) in provision for doubtful receivables, Impairment on investment property, Movement in fair value of derivative instruments, Dividend income.

${ }^{* *}$ TL 178.514.434 portion of tangible and intangible assets purchases in total of TL 407.150.331 as of 31 December 2009 was financed through finance leases. (407.150.331178.514.434=228.635.897)

${ }^{* * * *}$ Other represent: Interest received, Dividends received, (Increase)/decrease in short term financial investments.

The elements prezented in Consolidated Statement of Cash Flow are shown detailed in The Notes to Financial Statement.

\section{Romania}

Internationally, normalization rules aimed at designing the rules, this being completed by the International Accounting Standards Committee (International Accounting Standards Committee). Focusing the efforts of European Union resulted in the development of the directives, each state being awarded to their obligation to incorporate in their legislation.

Fourth Directive, aimed the coordination of national regulations of the structure and content of annual accounts and management of relationships, the rules for valuing assets, as well as publication of documents for companies. Member States were obliged to enter into their national legislation regulations on the scope of this Directive.

Seventh Directive covers the consolidated accounts and was adopted on 13 June 1983 by the European Union, as the result of international studies, of the normalization and standardization efforts in preparing and presenting consolidated accounts.

National legislation on how to prepare financial statements is regulated by the Ministerial Order No. 3055/2009 approving the public finances in accordance with European Regulations, published in Official Gazette no. 766bis of 10 November 2009.

Under this rule, the companies which at the date of the financial statement at the balance sheet exceed two of three criteria: total assets: 3.65 million euro, net income: EUR 7.3 million, the average number of employees during the year: 50, must prepare annual accounts including: balance sheet, income statement, statement of changes in equity, cash flow statement and explanatory notes to the annual financial statements.

"The balance sheet is the summary document that describes the assets, liabilities and equity of the entity's financial year and in other cases provided by law. In the balance sheet assets and liabilities are grouped according to nature and liquidity of the nature and enforceability. "(OMPF 3055/2009, Chapter II, point 20, paragraph 1 and 2)

In shape, the profit and loss statement may present bilateral (horizontal scheme) or as a list (vertical scheme). In our country it was formally adopted the list because it has the advantage of defining the current activity related outcome (operational and financial) of the outcome of the extraordinary activity. 
Cash flow statement should report cash flows of the entity during the period classified by operating, investing and financing. Presentation of cash flow is optional for companies that do not meet the criteria under OMPF 3055/2009.

In Romania, the financial statement it is not integral published, but a series of indicators, for both Balance Sheet and Profit and Loss. This are exemplified in Tables 13 and 14.

Example: TAROM SA

Tabel no.13.

Financial indicators according to Balance Sheets

\begin{tabular}{|l|r|r|}
\hline & \multicolumn{1}{c|}{ (in lei) } \\
\hline & \multicolumn{1}{c|}{ December 31} \\
\hline Total fixed assets & \multicolumn{1}{c|}{$\mathbf{2 0 0 9}$} & \multicolumn{1}{c|}{$\mathbf{2 0 0 8}$} \\
\hline Total current assets, composed by: & $1,246,583,619$ & $1,179,659,483$ \\
\hline Inventory & $990,779,910$ & $1,183,980,359$ \\
\hline Receivables & $36,709,503$ & $39,350,502$ \\
\hline Cash and deposits & $93,801,434$ & $87,221,216$ \\
\hline Anticipated Expenditure & $30,400,985$ & $30,349,496$ \\
\hline Total Debt & $6,216,311$ & $49,519,906$ \\
\hline Anticipated Revenue & $429,205,052$ & $464,700,883$ \\
\hline Loss provisions & $39,444,805$ & $39,388,884$ \\
\hline Total capital & $30,812,824$ & $17,304,948$ \\
\hline Paid-in capital & $1,800,027,159$ & $1,891,765,033$ \\
\hline Source wWW & $2,038,434,355$ & $1,974,470,085$ \\
\hline
\end{tabular}

Source: www.doingbusiness.ro and www.mfinante.ro

Tabel no.14.

Financial Indicators according to Profit and Loss

\begin{tabular}{|l|r|r|}
\hline & \multicolumn{1}{c|}{ (in lei) } \\
\hline & \multicolumn{2}{c|}{ December 31 } \\
\hline Annual turnover & $\mathbf{2 0 0 9}$ & \multicolumn{2}{|c|}{} \\
\hline Total revenues & $811,945,430$ & $944,202,571$ \\
\hline Total expences & $1,111,891,201$ & $1,407,615,756$ \\
\hline Profit before tax & $1,346,585,969$ & $1,413,929,225$ \\
\hline Net profit & $(234,694,768)$ & $(6,313,469)$ \\
\hline & $(234,723,435)$ & $(6,313,469)$ \\
\hline Number of employees & & \\
\hline
\end{tabular}

Source: www.doingbusiness.ro and www.mfinante.ro

\section{Comparison of the components of annual reports subject of research}

After presenting the three components of financial statements of companies we analyzed compared if the items in the balance sheet are presented in the same order or have the same name (Table no. 15).

Table no. 15.

Balance sheet

\begin{tabular}{|l|l|l|l|l|l|}
\hline & $\begin{array}{c}\text { Delta } \\
\text { Airlines }\end{array}$ & \multicolumn{1}{c|}{$\begin{array}{c}\text { British } \\
\text { Airways }\end{array}$} & \multicolumn{1}{c|}{$\begin{array}{c}\text { Air France- } \\
\text { KLM }\end{array}$} & $\begin{array}{c}\text { Turkish } \\
\text { Airline }\end{array}$ & \multicolumn{1}{|c|}{ Tarom SA } \\
\hline Current assets & Yes & $\begin{array}{l}\text { Yes, but after non- } \\
\text { current assets } \\
\text { Yes, but after non- } \\
\text { current assets }\end{array}$ & $\begin{array}{l}\text { Yes, are called current } \\
\text { assets and are prezented } \\
\text { after fixed assets }\end{array}$ \\
\hline Non-current assets & Yes & $\begin{array}{l}\text { Yes, but is the first } \\
\text { element }\end{array}$ & $\begin{array}{l}\text { Yes, but is the first } \\
\text { element }\end{array}$ & Yes & $\begin{array}{l}\text { Yes, are called fixed } \\
\text { assets }\end{array}$ \\
\hline Total assets & Yes & Yes & Yes & Yes & Yes \\
\hline Current Liabilities & Yes & $\begin{array}{l}\text { Yes, but after non- } \\
\text { current liabilities }\end{array}$ & $\begin{array}{l}\text { Yes, but after non- } \\
\text { current liabilities }\end{array}$ & Yes & Yes \\
\hline
\end{tabular}




\begin{tabular}{|l|l|l|l|l|l|}
\hline $\begin{array}{l}\text { Non-current } \\
\text { Liabilities }\end{array}$ & Yes & $\begin{array}{l}\text { Yes, but after } \\
\text { shareholder's } \\
\text { equity }\end{array}$ & $\begin{array}{l}\text { Yes, but after } \\
\text { shareholder's equity }\end{array}$ & Yes & Yes \\
\hline $\begin{array}{l}\text { Stockholder's } \\
\text { Equity }\end{array}$ & Yes & Yes & Yes & Yes & Yes \\
\hline $\begin{array}{l}\text { Total Equity and } \\
\text { Liabilities }\end{array}$ & Yes & Yes & Yes & Yes & Yes \\
\hline Observations & $\begin{array}{l}\text { The same elements } \\
\text { presented in another } \\
\text { order }\end{array}$ & $\begin{array}{l}\text { The same elements } \\
\text { presented in another } \\
\text { order }\end{array}$ & $\begin{array}{l}\text { The same elements } \\
\text { presented in another } \\
\text { order }\end{array}$ \\
\hline
\end{tabular}

Income Statement contains a number of common elements, but also some differences. Some statements show the income and expenditure by the type of activities (Exploitation, financial and extraordinary) other shows the financial result as the difference between revenues and expenditures, presenting only the influence of taxes or charges. (Table no. 16.)

Table no. 16.

Income Statement

\begin{tabular}{|l|l|l|l|l|l|}
\hline & \multicolumn{1}{|c|}{$\begin{array}{c}\text { Delta } \\
\text { Airlines }\end{array}$} & $\begin{array}{c}\text { British } \\
\text { Airways }\end{array}$ & $\begin{array}{c}\text { Air France- } \\
\text { KLM }\end{array}$ & $\begin{array}{c}\text { Turkish } \\
\text { Airline }\end{array}$ & $\begin{array}{c}\text { Tarom } \\
\text { SA }\end{array}$ \\
\hline Operating Revenue & Yes & Yes & Yes & Yes & Yes \\
\hline Operating Expense & Yes & Yes & Yes & Yes & Yes \\
\hline Financial income & - & - & Yes & Yes & Yes \\
\hline Financial expenses & - & - & Yes & Yes & Yes \\
\hline Income (Loss) before income taxes & Yes & Yes & Yes & Yes & Yes \\
\hline Income Tax (Provision) Benefit & Yes & Yes & Yes & Yes & Yes \\
\hline Net income (Loss) & Yes & Yes & Yes & Yes & Yes \\
\hline Earnings (Loss) per Share & Yes & - & - & Yes & - \\
\hline
\end{tabular}

Changing the flow of cash and cash equivalents for the five companies mentioned above, is presented by grouping these variations on the same types of activities: operating activities, investment and financing. (Table no. 17)

Table no. 17.

Statement of Cash Flows

\begin{tabular}{|l|l|l|l|l|l|}
\hline & $\begin{array}{c}\text { Delta } \\
\text { Airlines }\end{array}$ & $\begin{array}{c}\text { British } \\
\text { Airways }\end{array}$ & $\begin{array}{c}\text { Air France- } \\
\text { KLM }\end{array}$ & $\begin{array}{c}\text { Turkish } \\
\text { Airline }\end{array}$ & $\begin{array}{c}\text { Tarom } \\
\text { SA }\end{array}$ \\
\hline Net cash Flows from operating activities & Yes & Yes & Yes & Yes & Yes \\
\hline Net cash from investing activities & Yes & Yes & Yes & Yes & Yes \\
\hline Net cash from financing activities & Yes & Yes & Yes & Yes & Yes \\
\hline $\begin{array}{l}\text { Net Increase (Decrease) in cash and cash } \\
\text { equivalents }\end{array}$ & Yes & Yes & Yes & Yes & Yes \\
\hline $\begin{array}{l}\text { Cash and cash equivalents at beginning of } \\
\text { period }\end{array}$ & Yes & Yes & Yes & Yes & Yes \\
\hline Cash and cash equivalents at end of period & Yes & Yes & Yes & Yes & Yes \\
\hline
\end{tabular}

\section{Conclusions}

Annual financial statements as the product of accounting is not an end in itself but as means of representing the business, which, when decoded, interpreted and valued, should be the correct base of economic and financial decisions of users. (Berheci Maria, 2010)

The financial statement shows the assets of the entity and the structure of those assets and source of funding. The form of the financial statement issued by the Romanian national standards represents the elements into a mandatory structure and order, unlike the balance sheet format presented by international standards which provide only a list of them. 
Profit and Loss statement provides information regarding the amount of the results of activity given the current accounting income, through the relationship of income and expenditures which have led to their achievement. In these situations, the costs may be presented by types of expenditure, by nature or by function.

Cash flow statement shows sources of liquidity and how it was spent, identifying any discrepancies between net incomes and operating cash flows.

Whatever form of presentation of financial reporting describe by the accounting rules, national and international, they shed light on disclosure of information from the annual financial statements that the user can retrieve the necessary data to its objectives.

Theoretical model of the standard financial reporting forms which would be produced in a given country will accelerate the search for such reporting and analysis utility. The characteristic formulation of accounting and financial information is to achieve a common language in the reporting of financial data to be used by readers in the same sense, to be useful for all participants, can be comparable. (Briciu Sorin, 2009)

If in terms of composition and architecture of the financial statements presented in our study are comparable, remains to be investigated if the information released are comparable and which should be factors that would ensure or it would make it impossible comparability.

\section{References}

1. Berheci M., 2010. Recovery of financial reporting, Bucharest, Published by CECCAR

2. Briciu S., 2006. Managerial Accounting. Theoretical and practical aspects, Bucharest, Economic Publishing

3. Briciu S., Groza C., Gânfãlean I., 2009, International financial reporting standard (IFRS) will support management accounting system for small and medium enterprise (SME)?, Annales Universitatis Apulensis Series Oeconomica, 11(1), 2009

4. Cernuşcă L., 2004. Strategies and accounting policies, Bucharest, Economic Publishing

5. Feleagă N., 2000. Comparative accounting systems, Second edition, vol. II International accounting rules, Bucharest Economic Publishing

6. Ionescu C., 2003. Financial information in the context of internationalization of accounting, Bucharest, Economic Publishing

7. Lungu C.-I., 2007. Accounting theory and practice on preparing and presenting financial statements, Bucharest, Published by CECCAR

8. Ristea M., Olimid L., Calu D. Artemisa, coordinators, 2006. Compared to accounting systems, Bucharest, Published by CECCAR

9. Ministry of Finance, 2001, Practical guide to International Accounting Standards, Part I, Bucharest, Economic Publishing

10. OMFP 3055/2009 for the approval of the Official Gazette in accordance with European directives published in the Official Gazette of 10 November 2009 766bis.

11. http://images.delta.com.edgesuite.net/delta/pdfs/annual_reports/2010_10K.pdf found on March 26, 2011

12. http://www.britishairways.com/cms/global/microsites/ba_reports0910/pdfs/Financial_statem ents.pdf consulted on 26 March, 2011

13. http://www.airfranceklm-finance.com/financial-publications.html found on March 27, 2011

14. http://www.turkishairlines.com/en-INT/corporate/investor_relations/financials.aspx consulted 28 March 2011

15. http://www.comptabilite-move.com/comptabilite-en-france/les-objectifs-hypotheses-etcaracteristiques-qualitatives-des-etats-financiers-2/ found on March 27, 2011

16. http://www.doingbusiness.ro/financial/report/946521/compania-nationala-de-transporturiaeriene-romane-tarom-sa/ found on March 29, 2011 